\title{
First record and extended distribution of Otothyropsis piribebuy (Loricariidae: Hypoptopomatinae) in Brazil
}

\author{
Guilherme Seiji Hocama ${ }^{1,4}$; Fernanda de Oliveira Martins ${ }^{1,2,5}$ \& Francisco Severo-Neto ${ }^{3,6}$ \\ ${ }^{1}$ Instituto Federal de Educação, Ciência e Tecnologia do Paraná (IFPR). Londrina, PR, Brasil. \\ ${ }^{2}$ Universidade Estadual de Londrina (UEL), Centro de Ciências Biológicas (CCB), \\ Departamento de Biologia Animal e Vegetal (BAV), Museu de Zoologia (MZUEL). Londrina, PR, Brasil. \\ 3 Universidade Federal de Mato Grosso do Sul (UFMS), Instituto de Biociências (INBI0), Setor de Zoologia, \\ Coleção Zoológica de Referência (ZUFMS). Campo Grande, MS, Brasil. \\ 4 ORCID: http://orcid.org/0000-0001-5070-4899. E-mail: guiseiji@gmail.com \\ ${ }^{5}$ ORCID: http://orcid.org/0000-0003-0673-7751.E-mail: fernanda_martins2@hotmail.com \\ ${ }^{6}$ ORCID: http://orcid.org/0000-0002-1912-8237. E-mail: netosevero@hotmail.com
}

\begin{abstract}
Cascudinhos are a group of small benthic fishes included in the Hypoptopomatinae subfamily, inhabiting small to moderate streams and rivers within the Neotropical region, from Venezuela to Northern Argentina. Until now, Otothyropsis piribebuy originally described from the rio Paraguay basin, in Paraguay, is the only species of the genus not recorded in Brazil. Recent samples in the rio Tererê, rio Paraguay basin, Brazil, revealed a population of Otothyropsis with uncertain taxonomic identity. Therefore, the study aimed to unveil the distribution of Otothyropsis within Brazilian territory. External morphology, osteology, measurements, and counts (plates, teeth, and rays) of these specimens from rio Tererê were compared to data from the original description of 0 . piribebuy, and also with specimens of 0 . piribebuy sampled in Paraguayan territory. Observations indicated no differences among the analyzed specimens. Furthermore, a Principal Component Analysis (PCA), carried out using log-transformed measures from Brazilian and Paraguayan specimens, showed no separation of these populations, also indicating that all analyzed specimens pertain to the same species. Based on this, a prediction map of distribution, using Maximum Entropy, was produced. The correct identification of spatial range of occurrence is an essential step to ensure the conservation of species, and the extended distribution of Otothyropsis piribebuy was confirmed, enhancing the list of neotropical fish from Brazil.
\end{abstract}

Key-Words. Cascudinhos; Pantanal; Upper Paraguay basin; Chaco; Ichthyofauna.

\section{INTRODUCTION}

Cascudinhos are a group of small benthic fishes included in the Hypoptopomatinae subfamily, inhabiting small to moderate streams and rivers within the Neotropical region, from Venezuela to Northern Argentina (Schaefer, 2003). Within the group, Otothyropsis Ribeiro, Carvalho \& Melo, 2005 was described to allocate O. marapoama Ribeiro, Carvalho, Melo, 2005, a species from the rio Paraná basin. Currently, there are six valid species for the genus, belonging to the rio Paraná and the rio Paraguay basins: O. alicula Lippert, Calegari, Reis, 2014, O. biamnicus Calegari, Lehmann, Reis, 2013, O. dialeukos Calegari, Molis, Reis, 2017, O. marapoama, O. piribebuy Calegari, Lehmann, Reis, 2011, and O. polyodon Calegari, Lehmann, Reis, 2013.

Otothyropsis piribebuy, from rio Paraguay basin, is known exclusively from Paraguayan territo- ry (Fig. 1 - star, square and triangle). This species is distinguished from the congeners by possessing the lateral middle series of plates truncated before the caudal fin; the inner margin of pectoral

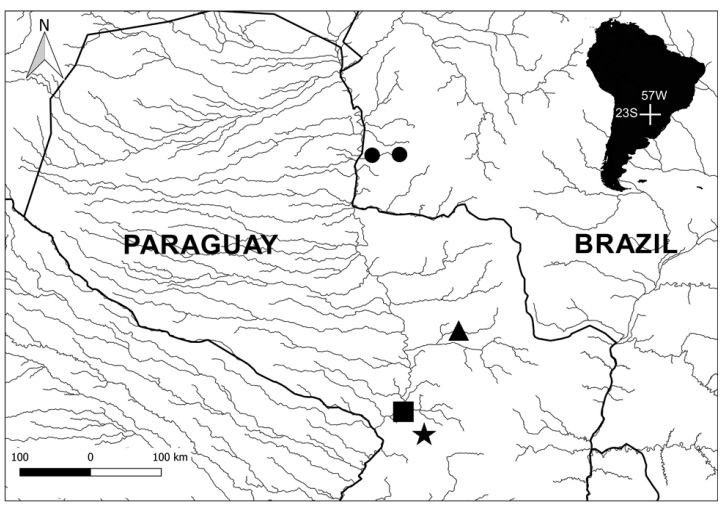

Figure 1. Distribution of Otothyropsis piribebuy within the rio Paraguay basin. Star = holotype; square $=$ paratype; triangle $=$ non-type, from Paraguay. Circles $=$ new occurrence in Brazil. 
spine fin smooth; the distal tip of the first ceratobranchial accessory flange pointed; and abdomen with unplated areas in adults (Calegari et al., 2011). Recent examination of specimens sampled in the rio Tererê, rio Paraguay basin, Mato Grosso do Sul, Brazil (Fig. 1 - circles), revealed the first record of $O$. piribebuy in Brazilian territory, extending the occurrence area of the species.

\section{MATERIAL AND METHODS}

Sampling occurred in Pantanal floodplain, rio Tereré drainage, transition between the Nabileque subregion and Chaco domain. Fishes were collected on shaded rapids of temporary shallow streams, locally known as "vazantes", usually associated with submerged twigs, and co-occurring with shoals of another Hypoptopomatinae, Otocinclus bororo Schaefer, 1997.

Comparison of specimens were based on counts and measurements following Schaefer (1997), and compilation proposed by Martins et al. (2014) with additional measurements from Calegari et al. (2011). Measurements were obtained using digital calipers ( $\pm 0.1 \mathrm{~mm}$ ), point-to-point, under a stereomicroscope on the left side of 17 specimens [13 from Brazil (ZUFMS 5718) and 4 from Paraguay (MNRJ 26113)]. Morphometric data are expressed as a percent of standard length $(\mathrm{SL})$ for body, or head length $(\mathrm{HL})$ for cephalic subunits. For osteological examination, three specimens were cleared and stained (c\&s), following Taylor \& Van Dyke (1985) (2 from ZUFMS 5718 and one from MNRJ 26113). All obtained results were compared with data from the original description of Otothyropsis piribebuy. Principal Component Analysis (PCA) was carried out using log-transformed measures from the same specimens used in morphometrics analysis, in R environment (R Core Team, 2019), with ggbiplot (Vincent, 2011) and stats (R Core Team, 2019) packages.

Distribution map was produced using QGis (QGIS Development Team, 2019), with dataset from FAO Fisheries \& Aquaculture Department (FAO Fisheries \& Aquaculture Department, 2019). Prediction of the distribution of species were performed using Maximum Entropy - relying on probability of occurrence based of presence-only data from available sample sites (CZCEN 332, MCP 45754, MNRJ 26113, ZUFMS 5717, ZUFMS 5718) using MaxEnt (Phillips et al., 2019) and environmental datasets - maximum, average and minimum temperature and precipitation, besides a climatic biological dataset (see worldclim.com for detailed information) - from WorldClim (Fick \& Hijmans, 2017).

Institutional abbreviations: CZCEN = Colección Zoológica de la Facultad de Ciencias Exactas y Naturales, Universidad Nacional de Asunción, Asunción; MCP = Museu de Ciências e Tecnologia, Pontíficia Universidade Católica do Rio Grande do Sul, Porto Alegre; MNRJ = Museu Nacional, Rio de Janeiro; ZUFMS = Coleção Zoológica de Referência da Universidade Federal de Mato Grosso do Sul, Campo Grande.

\section{RESULTS}

To compare the specimens of Otothyropsis collected in Brazilian portions of the Paraguay basin (ZUFMS 5718, Fig. 2), specimens of $O$. piribebuy sampled near the type-locality in the Paraguay were examined (MNRJ 11256), as well as the data from the original description given by Calegari et al. (2011). Based on comparison of meristic and morphometric data (Tables 1-2), external morphology, and osteological features the specimens were identified as Otothyropsis piribebuy.

Principal Component Analysis (PCA), based on populations of Otothyropsis piribeuy from Brazilian and Paraguayan portions of rio Paraguay basin, corroborated the conspecificity, indicating no differences between the two populations (Fig. 3). The two distinct groups showed on PCA result were separated based strictly on sexual dimorphism. The first group clustered all females specimens, while the second group united the males. Calegari et al. (2011) had already pointed the sexual dimorphism as an important feature of this species.

Considering the sampling locations and their morphoclimatic features, a prediction map was constructed (Fig. 4), which revealed a greater potential extent of occurrence for $\mathrm{O}$. piribebuy. The orange areas on the map are regarded as the most probable of occurrence, representing putative sampling sites.

\section{DISCUSSION}

The majority of morphometric and meristic features of the specimens from rio Tererê, Brazil, were consistent with those of the type series of $O$. piribebuy, as given by Calegari et al. (2011). Also, considering the diagnostic features for 0 . piribebuy, the same patterns were observed in Brazilian specimens, such as the number and truncation of lateral series of plates, lack of serration in internal margin of the pectoral-fin spine, and abdominal pattern of plating. An osteological variation identified in one specimen was the fusion of infraorbitals 2 and 3, revealing an intraspecific exception.

The PCA showed no distinction between the two compared populations from Brazil and Paraguay, but was efficient to separate males and females (Fig. 3), corroborating the sexual dimorphism already known to O. piribebuy. Besides the two most common characteristics used to identify sexual dimorphism within Hypoptopomatinae (the fleshy flap above the first pelvic-fin ray and the urogenital papilla), the males also shared other secondary sexual dimorphism features, such as the enlarged nostril and smaller internarial distance as many other Hypoptopomatinae species (e.g., Calegari et al., 2011; Martins \& Langeani, 2011).

Otothyropsis congeners have been described from Brazilian waters recurrently (Ribeiro et al., 2005; Calegari et al., 2011, 2013; Lippert et al., 2014) except for O. dialeukos, found in rio Paraná basin, and O. piribebuy, from rio Paraguay basin, both in Paraguayan territory (Calegari et al., 2011, 2017). This is the first record of O. piribebuy in 
Brazil, extending the distribution of the species in the rio Paraguay basin. The collecting sites of $O$. piribebuy are relatively distant from each other (Fig. 1). However, a similar distribution pattern, with a large gap between collecting sites in the rio Paraguay basin, was already described for two non-loricariid species - Tatia neivai (lhering, 1930) and Gymnotus pantanal Fernandes, Albert, Daniel-Silva, Lopes, Crampton \& Almeida-Toledo, 2005 (SarmentoSoares \& Martins-Pinheiro, 2008; Craig et al., 2018).
It is noteworthy that the collections occurred six months apart within two distinct hydrological moments (flood and drought seasons), and despite the effort to locate the species on other habitats, specimens of $O$. piribebuy were only found on those two locations (Fig. 1 - circles). Although the flooding is known as a driver of homogenization of fish communities of floodplain systems(Thomaz et al., 2007), the specificity of occupation observed on $O$. piribebuy emphasizes the need

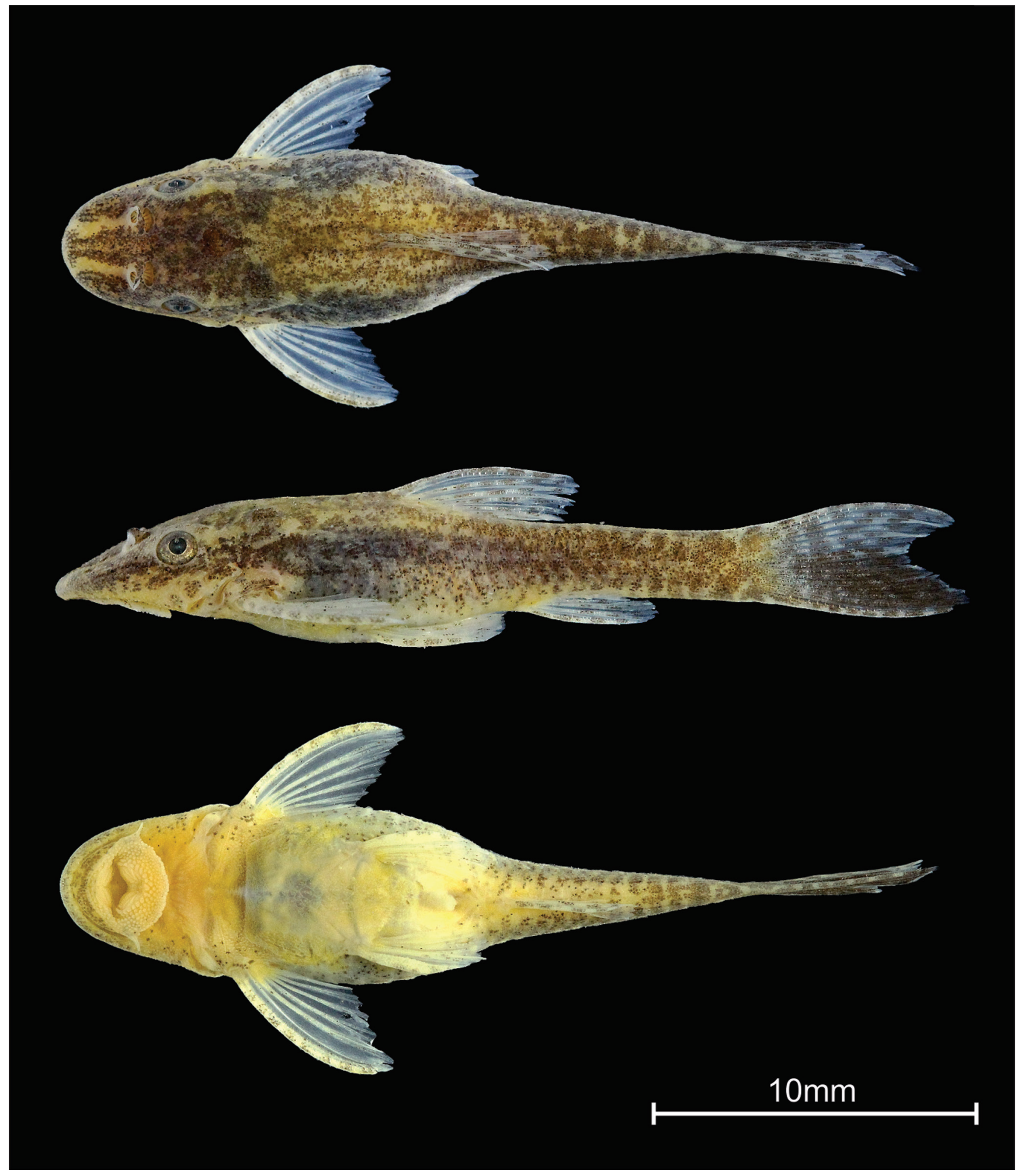

Figure 2. Otothyropsis piribebuy, nontype, first record in Brazilian territory, ZUFMS 5796, 23.8 mm SL, female, Rego d’Água, Porto Murtinho, Mato Grosso do Sul, Brazil. 
Table 1. Meristic data of Otothyropsis piribebuy, new occurrence, specimens collected in Mato Grosso do Sul, Brazil.

\begin{tabular}{|c|c|c|c|}
\hline Character & $\mathrm{N}$ & Range & Distribution frequency \\
\hline Teeth in left premaxilla & 15 & $10-17$ & $10(2), 12(2), 13(6), 14(3), 16(1), 17(1)$ \\
\hline Teeth in right premaxilla & 15 & $9-16$ & $9(1), 10(1), 12(3), 13(4), 14(4), 15(1), 16(1)$ \\
\hline Teeth in left dentary & 15 & $9-15$ & $9(1), 10(3), 11(3), 12(3), 13(5), 15(1)$ \\
\hline Teeth in right dentary & 15 & $9-16$ & $9(1), 10(2), 11(6), 12(1), 13(2), 14(1), 16(1)$ \\
\hline Dorsal plates & 2 & $20-21$ & $20(1), 21(1)$ \\
\hline Mid-dorsal plates & 2 & 17 & $17(2)$ \\
\hline \multicolumn{4}{|l|}{ Median plates } \\
\hline Anterior field plates ${ }^{+}$ & 2 & 3-5 & $3(1), 4(2), 5(1)$ \\
\hline Gap field plates $^{+}$ & 2 & $1-2$ & $1(2), 2(2)$ \\
\hline Posterior field plates ${ }^{\dagger}$ & 2 & $15-16$ & $15(3), 16(1)$ \\
\hline Midventral plates ${ }^{\dagger}$ & 2 & $17-18$ & $17(2), 18(2)$ \\
\hline Ventral plates ${ }^{\dagger}$ & 2 & $17-18$ & $17(1), 18(3)$ \\
\hline Total vertebrae & 2 & 27 & $27(2)$ \\
\hline Upper pharyngeal plate teeth $^{\dagger}$ & 2 & $18-19$ & $18(2), 19(2)$ \\
\hline Ceratobranchial 5 teeth & 2 & 11 & $11(2)$ \\
\hline Dorsal-fin branched rays & 15 & $6-7$ & $6(1), 7(14)$ \\
\hline Pectoral-fin branched rays & 15 & 6 & $6(15)$ \\
\hline Pelvic-fin branched rays & 15 & 5 & $5(15)$ \\
\hline Anal-fin branched rays & 15 & 5 & $5(15)$ \\
\hline Caudal-fin branched rays & 15 & $13-14$ & $13(1), 14(14)$ \\
\hline Dorsal procurrent rays & 15 & $1-2$ & $1(4), 2(11)$ \\
\hline Ventral procurrent rays & 15 & $1-2$ & $1(13), 2(2)$ \\
\hline
\end{tabular}

${ }^{\dagger}$ Counting in right and left sides.

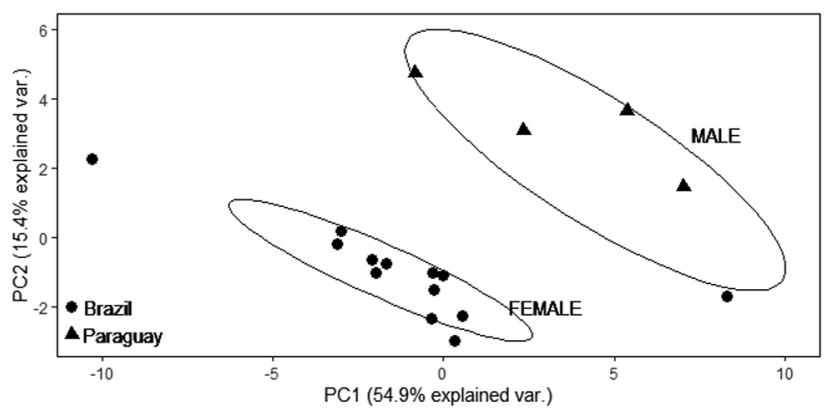

Figure 3. Principal Component Analysis (PCA) using specimens of Otothyropsis piribebuy from both Paraguayan $(\boldsymbol{\Delta})$ and Brazilian $(\mathbf{O})$ territories. The two distinct clusters represent males and females, evidencing the sexual dimorphism present in the species.

for further fieldworks in upper the rio Paraguay basin environments in order to fill gaps on the ichthyological knowledge of this drainage. This is corroborated by the prediction map of distribution to O. piribebuy (Fig. 4), according to which, the species probably exists in other portions of the basin.

\section{CONCLUSION}

From the registration of 0 . piribebuy in Brazilian territory, is important to included it on future checklists and consequently evaluate the conservation status of

Table 2. Morphometric data of Otothyropsis piribebuy. Data to holotype and paratypes were obtained from original description of the species in Calegari, Lehmann $\&$ Reis (2011). Min = minimum, Max = maximum, SD = Standard Deviation.

\begin{tabular}{|c|c|c|c|c|c|c|c|c|c|c|c|}
\hline & \multicolumn{7}{|c|}{ Paraguayan territory } & \multirow{2}{*}{\multicolumn{4}{|c|}{$\begin{array}{c}\text { Brazilian territory } \\
\text { New occurence }=13\end{array}$}} \\
\hline & \multirow{2}{*}{ Holotype } & \multicolumn{6}{|c|}{ Non-type $=19$} & & & & \\
\hline & & Low & High & Min & Max & Mean & SD & Min & Max & Mean & SD \\
\hline Standart lenght (mm) & 28.8 & 22.3 & 28.8 & 20.7 & 23.2 & 21.7 & - & 19.9 & 26.7 & 22.7 & - \\
\hline Head length & 35.0 & 33.4 & 37.8 & 32.3 & 36.1 & 34.2 & 2.1 & 35.6 & 41.1 & 37.2 & 1.4 \\
\hline Predorsal length & 47.6 & 46.5 & 50.5 & 47.7 & 49.7 & 49.0 & 0.9 & 47.0 & 49.9 & 48.8 & 1.0 \\
\hline Postdorsal length & 40.3 & 38.8 & 42.5 & 24.7 & 26.3 & 25.4 & 0.6 & 36.2 & 42.9 & 38.8 & 1.9 \\
\hline Preanal length & 64.4 & 63.0 & 67.4 & 63.4 & 65.3 & 64.4 & 0.8 & 63.6 & 68.0 & 65.9 & 1.5 \\
\hline Prepelvic length & 43.4 & 42.2 & 46.3 & 43.5 & 45.7 & 44.5 & 1.0 & 41.9 & 45.2 & 43.8 & 1.0 \\
\hline Cleithral width & 23.8 & 22.5 & 26.7 & 20.2 & 21.5 & 21.0 & 0.6 & 23.7 & 25.8 & 24.7 & 0.7 \\
\hline Thoracic length & 17.1 & 17.1 & 19.7 & 5.3 & 6.4 & 5.7 & 0.5 & 14.3 & 21.6 & 19.0 & 2.7 \\
\hline Abdominal length & 22.4 & 20.8 & 24.3 & 14.4 & 15.5 & 14.9 & 0.5 & 20.1 & 23.9 & 21.4 & 1.1 \\
\hline Dorsal-fin unbranched ray length & 24.8 & 24.8 & 29.8 & 26.0 & 27.3 & 26.5 & 0.6 & 25.3 & 28.7 & 27.1 & 1.1 \\
\hline Dorsal-fin base length & 13.2 & 12.2 & 14.7 & 11.5 & 14.2 & 13.0 & 1.2 & 13.0 & 15.6 & 14.1 & 0.9 \\
\hline Pectoral-fin spine length & 24.9 & 24.9 & 30.4 & 26.9 & 27.4 & 27.1 & 0.2 & 25.3 & 29.3 & 27.5 & 1.1 \\
\hline Pelvic-fin unbranched ray length & 15.0 & 13.7 & 19.7 & 15.7 & 22.3 & 18.7 & 2.7 & 14.8 & 19.2 & 16.8 & 1.3 \\
\hline Anal-fin unbranched ray length & 16.6 & 14.8 & 19.6 & 18.2 & 19.2 & 18.6 & 0.4 & 17.0 & 20.5 & 18.7 & 1.1 \\
\hline Caudal-peduncle length & 30.0 & 28.1 & 32.3 & 13.1 & 17.8 & 15.5 & 1.9 & 25.7 & 31.0 & 28.8 & 1.8 \\
\hline Caudal-peduncle depth & 10.1 & 9.7 & 11.5 & 9.7 & 10.9 & 10.4 & 0.5 & 9.2 & 10.6 & 9.7 & 0.4 \\
\hline Caudal-peduncle width & 6.8 & 5.9 & 7.4 & 5.2 & 8.5 & 6.3 & 1.5 & 6.7 & 10.6 & 8.3 & 1.2 \\
\hline Body depth at dorsal-fin origin & 15.8 & 15.0 & 19.2 & 16.0 & 19.0 & 17.2 & 1.3 & 14.2 & 16.8 & 15.4 & 0.8 \\
\hline Body width at dorsal-fin origin & 19.5 & 16.2 & 22.7 & 21.5 & 21.9 & 21.7 & 0.2 & 16.2 & 20.8 & 18.1 & 1.4 \\
\hline Head depth & 45.7 & 41.4 & 52.1 & 43.7 & 48.4 & 46.3 & 1.9 & 41.2 & 45.4 & 43.2 & 1.6 \\
\hline Snout length & 50.2 & 47.1 & 53.2 & 48.4 & 54.6 & 51.0 & 2.6 & 46.3 & 52.0 & 49.5 & 1.7 \\
\hline Orbital diameter & 12.3 & 12.3 & 15.1 & 17.9 & 19.7 & 18.7 & 0.8 & 15.6 & 18.1 & 17.1 & 0.8 \\
\hline Interorbital width & 40.9 & 38.4 & 45.8 & 42.6 & 45.7 & 44.2 & 1.3 & 38.0 & 43.5 & 41.4 & 1.6 \\
\hline Internareal width & 14.4 & 6.3 & 15.9 & 9.0 & 10.7 & 9.5 & 0.8 & 7.2 & 10.9 & 9.8 & 0.9 \\
\hline Prenasal length & 35.8 & 28.9 & 36.4 & 28.5 & 30.9 & 29.9 & 1.0 & 29.6 & 34.7 & 31.9 & 1.6 \\
\hline Barbel length & 9.2 & 6.4 & 10.9 & 4.6 & 6.7 & 5.9 & 0.9 & 4.9 & 8.7 & 6.3 & 1.2 \\
\hline
\end{tabular}




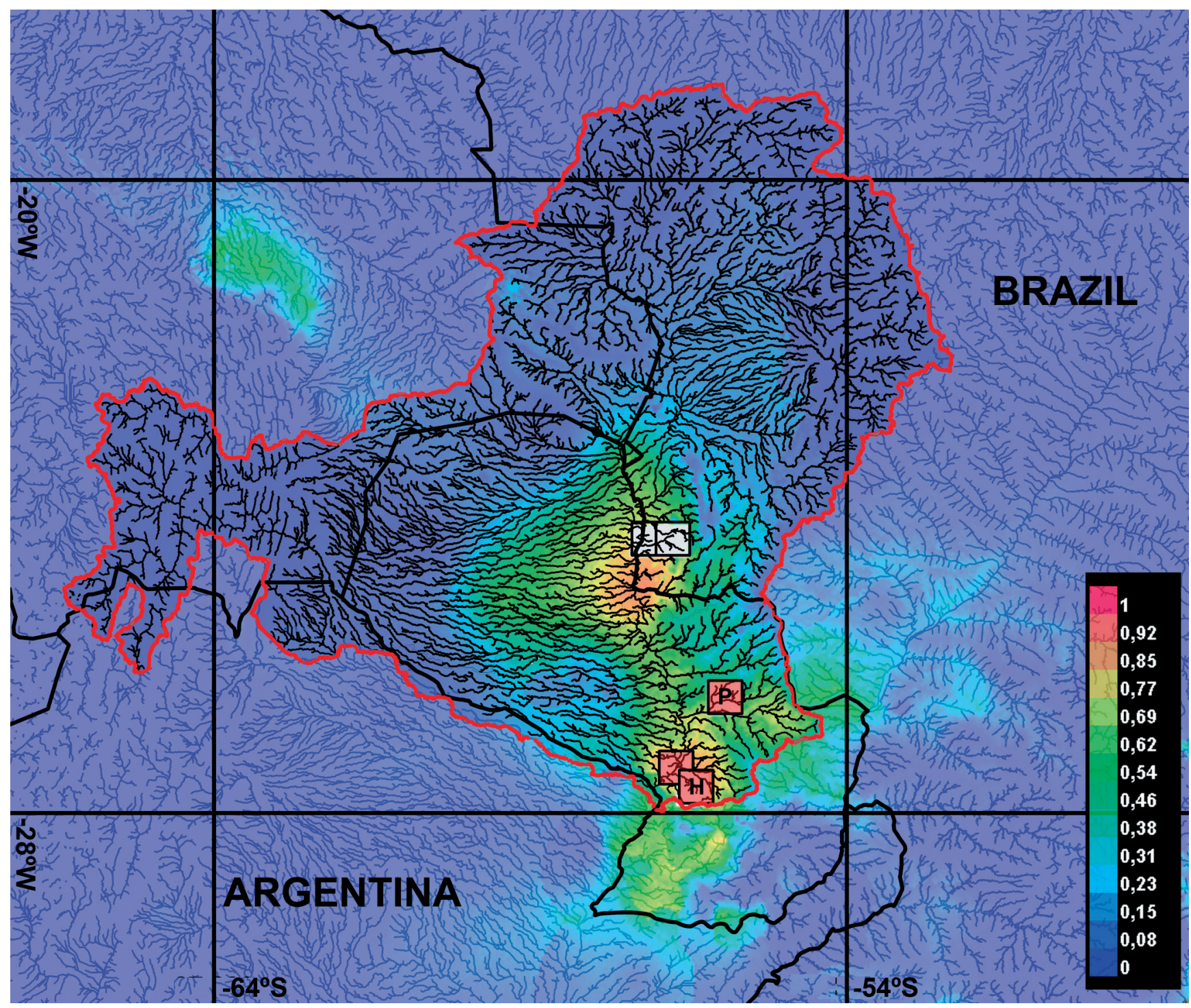

Figure 4. Prediction map of occurrence, with higher values on scale representing chances of captures. Black line: country boundaries. Red line: rio Paraguay basin limits. Red squares: Paraguayan sampling sites - holotype (H), paratypes $(\mathrm{P})$, and non-type specimens examined. White squares: new occurrence in Brazilian territory.

this species in Brazil, based on the International Union for Conservation of Nature (IUCN) categories and criteria, during the next process of evaluation of species promoted by the Instituto Chico Mendes de Conservação da Biodiversidade (ICMBio).

\section{MATERIAL EXAMINED}

Otothyropsis piribebuy: MNRJ 26113, 5 (1 c\&s), 20.68-23.15 mm SL; Arroio Yguarasesauna, Ypacaraí, Cordilhera, Paraguay $\left(25^{\circ} 02^{\prime} 19^{\prime \prime} \mathrm{S}, 57^{\circ} 01^{\prime} 00^{\prime \prime} \mathrm{W}\right)$. ZUFMS 5717, 17, Vazante do retiro Piquete, on Farm Tereré, Porto Murtinho, Mato Grosso do Sul, Brazil $\left(21^{\circ} 22^{\prime} 06^{\prime \prime} S\right.$, $57^{\circ} 42^{\prime} 34^{\prime \prime}$ ). ZUFMS 5718, 21, Rego d'água on Farm Tereré, Porto Murtinho, Mato Grosso do Sul $\left(21^{\circ} 21^{\prime} 23^{\prime \prime} \mathrm{S}\right.$, $57^{\circ} 36^{\prime} 45^{\prime \prime}$ W). ZUFMS 5795, 3, Vazante do Retiro Piquete, on Farm Tereré, Porto Murtinho, Mato Grosso do Sul,

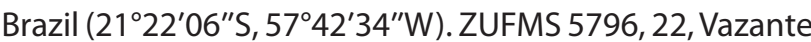
do Retiro Piquete, on Farm Tereré, Porto Murtinho, Mato Grosso do Sul, Brazil $\left(21^{\circ} 22^{\prime} 06^{\prime \prime} \mathrm{S}, 5^{\circ} 42^{\prime} 34^{\prime \prime} \mathrm{W}\right)$.

\section{ACKOWLEDGEMENT}

We would like to thank Douglas Lopes and Thiago Taveira for assistance on field work, and Fazenda Tereré for allowing the entrance to sampling sites. The research was supported by Conselho Nacional de Desenvolvimento Científico e Tecnológico (CNPq, Process 425695/2018-2 (FOM)), and the Programa Institucional de Bolsas de Iniciação Científica (PIBIC-IFPR (GSH)).

\section{REFERENCES}

Calegari, B.B.; Lehmann, A. \& Reis, R.E. 2011. A new species of Otothyropsis (Siluriformes: Loricariidae) from the rio Paraguay basin, Paraguay. Neotropical Ichthyology, 9(2): 253-260. D0I

Calegari, B.B.; Morlis, W.G. \& Reis, R.E. 2017. A new species of Otothyropsis (Siluriformes: Loricariidae) from the upper rio Paraná basin, Paraguay, with a discussion of the limits between Otothyropsis and Hisonotus. Zootaxa, 4244(2): 231. D01 
Calegari, B.B.; Pablo, L.A. \& Reis, R.E. 2013. Two new species of cascudinhos of the genus Otothyropsis (Siluriformes: Hypoptopomatinae) from the rio Paraná basin, Brazil. Zootaxa, 3619(2): 130-144. D01

Craig, J.M.; Malabarba, L.R.; Crampton, W.G.R. \& Albert, J.S. 2018. Revision of banded knifefishes of the Gymnotus carapo and G. tigre clades (Gymnotidae: Gymnotiformes) from the Southern Neotropics. Zootaxa, 4379(1): 47-73. DOI

FA0 Fisheries \& Aquaculture Department. 2019. Rivers in South America - derived from HydroSHEDS. Available at: http://www.fao.org/ geonetwork?uuid=12d7d96a-b0ea-4aea-aedc-b9c9a80cab7f. Access in: 04/11/2019.

Fick, S.E. \& Hijmans, R.J. 2017. WorldClim 2: new 1-km spatial resolution climate surfaces for global land areas. International Journal of Climatology, 37(12): 4302-4315. D0I

Lippert, B.G.; Calegari, B.B. \& Reis, R.E. 2014. A New Species of Otothyropsis (Siluriformes: Hypoptopomatinae) from Eastern Brazil. Copeia, 2014(2): 238-244. DOI

Martins, F.0. \& Langeani, F. 2011. Microlepidogaster dimorpha, a new species of Hypoptopomatinae (Siluriformes: Loricariidae) from the upper rio Paraná system. Neotropical Ichthyology, 9(1): 79-86. D01

Martins, F.0.; Britski, H.A. \& Langeani, F. 2014. Systematics of Pseudotothyris (Loricariidae: Hypoptopomatinae). Zoological Journal of the Linnean Society, 170(4): 822-874. D0I

Phillips, S.J.; Dudik, M. \& Schapire, R.E. 2019. Maxent software for modeling species niches and distributions (Version 3.4.1). Available at: https:// biodiversityinformatics.amnh.org/open source/maxent. Access in: 10/04/2019.
QGIS Development Team. 2019. QGIS Geographic Information System. Open Source Geospatial Foundation Project. Available at: https://www.qgis. org/pt BR/site. Access in: 20/02/2019.

$R$ Core Team. 2019. R: A language and environment for statistical computing. Available at: https://www.r-project.org. Access in: 20/01/2019.

Ribeiro, A.C.; Carvalho, M. \& Melo, A.L. 2005. Description and relationships of Otothyropsis marapoama, a new genus and species of hypoptopomatine catfish (Siluriformes: Loricariidae) from rio Tietê basin, southeastern Brazil. Neotropical Ichthyology, 3(4): 489-498. D0I

Sarmento-Soares, L.M. \& Martins-Pinheiro, R.F. 2008. A systematic revision of Tatia (Siluriformes: Auchenipteridae: (entromochlinae). Neotropical Ichthyology, 6(3): 495-542. D0I

Schaefer, S.A. 1997. The Neotropical cascudinhos: Systematics and biogeography of the Otocinclus catfishes (Siluriformes: Loricariidae). Proceedings of the Academy of Natural Sciences of Philadelphia, 148: 1-120. DOI

Schaefer, S.A. 2003. Subfamily Hypoptopomatinae. In: Reis, R.E.; Kullander, S.0. \& Ferraris, C.J. (Eds.). Checklist of the freshwater fishes of South and Central America. Porto Alegre, EduPUCRS. p. 321-329.

Taylor, W.R. \& Van Dyke, G.C. 1985. Revised procedures for staining and clearing small fishes and other vertebrates for bone and cartilage study. Cybium, 9: 107-109.

Thomaz, S.M.; Bini, L.M. \& Bozelli, R.L. 2007. Floods increase similarity among aquatic habitats in river-floodplain systems. Hydrobiologia, 579(1): 1-13. DOI

Vincent, Q.V. 2011. ggbiplot: A ggplot2 based biplot. R package version 0.55 . 